УДК 615.273.53:616.831-005.1]:[61:001.8]

DOI https://doi.org/10.11603/2312-0967.2018.4.9688

\title{
АНТИТРОМБОЦИТАРНА ТЕРАПІЯ ІШЕМІЧНОГО ІНСУЛЬТУ 3 ПОЗИЦІЙ ДОКАЗОВОї МЕДИЦИНИ
}

\author{
(c) О. Р. Левицька
}

\author{
Львівський національний медичний університет імені Данила Галицького \\ levytska.oksana@gmail.com
}

\begin{abstract}
Мета роботи. Аналіз та систематизація даних кокранівських (КО), систематичних оглядів (СО) та метааналізів (MA) стосовно антитромбоцитарної терапії (АТT) при ішемічному інсульті (II) 3 урахуванням сучасних даних доказової медицини (ДМ).

Матеріали і методи. Методи: інфрормаційного пошуку, аналізу і синтезу. Проведено розширений пошук КО, СО та MA щодо ATT при II в базах ДМ DORIS та Medline (PubMed). Період проведення - липень 2018 р. У дослідження включено 4 КО та 14 СО і МА (повнотекстові огляди або абстракти). Систематизацію даних здійснювали за видом антиагреганта і видом лікування (моно- чи подвійна антиагрегантна терапія тощо).

Результати й обговорення. Проаналізовано і систематизовано дані щодо ефективності та безпеки використання ацетилсаліцилової кислоти (АСК), дипіридамолу, тиклопідину, клопідогрелю, блокаторів рецепторів глікопротеїну IIb/IIla (ептифібатиду, абсіксимабу, тирофрібану та ін.), цилостазолу, тикагрелору, трифрлузалу в гострому періоді II та його вторинній профрілактиці. Препаратом вибору для АТТ як в гострому періоді, так і 3 метою вторинної профрілактики II залишається АСК. У хворих, які мають протипоказання до призначення АСК, можливе використання альтернативних АA (зокрема, клопідогрелю). Ефективність та безпека одних блокаторів рецепторів глікопротеїну Ilb/IIla (тирофрібану та ептифрібатиду) не є достатньо достовірною, а використання інших (абсіксимаб тощо) при лікуванні гострого II € потенційно шкідливим і не повинно виконуватись. Питання ефективності та безпеки цих Л3 при II повинно досліджуватись у подальших випробовуваннях. Короткочасна подвійна АТТ (АСК+клопідогрель) $€$ корисною для ранньої профрілактики у хворих із малим інсультом.

Висновки. За результатами розширеного пошуку публікацій щодо АТТ при II в різних базах даних ДМ за липень 2018 р. встановлено, що питання ефективності, безпеки лікування різними антитромбоцитарними лз та їх комбінаціями й надалі залишається актуальним напрямом досліджень сучасної інсультології.
\end{abstract}

Ключові слова: ішемічний інсульт; антиагреганти; доказова медицина.

Вступ. Одним з основних напрямків патогенетичної терапії при ішемічному інсульті (II) вважають покращення перфузії тканини мозку (ранню реканалізацію судини й реперфузію). Серед методів реперфузії виділяють: тромболітичну, антикоагулянтну та антиагрегантну терапії $[1,2]$. Останню застосовують як в гострому періоді II, так і з метою вторинної проорілактики. Найважливішим підходом до вибору антиагрегантів (AА) при лікуванні II є орієнтація на дані доказової медицини (ДМ), зокрема кокранівські (КО), систематичні огляди (СО) та метааналізи (МА), яким притаманний найвищий рівень доказів есрективності, а за їх відсутності - на результати рандомізованих клінічних досліджень (РКД). У монографрії «Ішемічний інсульт: клініко-фрармацевтичні аспекти» (2014 р.) ми систематизували доказові дані щодо використання AА при II [3]. 3 того часу інсультологія поповнилася результатами нових досліджень, що і зумовило актуальність нашої наукової розвідки.

Мета роботи. Аналіз та систематизація даних КO, CO та MA стосовно антитромбоцитарної терапії (АТT) при II з урахуванням сучасних даних доказової медицини.
Матеріали і методи. Використано методи інорормаційного пошуку, аналізу і синтезу. Проведено розширений пошук публікацій (КО, СО, МА) щодо АТТ при II в таких базах даних ДМ, як DORIS (база даних досліджень в області інсульту (Database of Research in Stroke) [4] та Medline Національної медичної бібліотеки США (US National Library of Medicine, NLM) 3 ïi електронно-пошуковою системою PubMed [5]. Період дослідження - липень 2018 р. У дослідження включено 4 КО та 14 СО і МА (повнотекстові огляди або абстракти). Систематизацію даних щодо використання АА в гострому періоді інсульту та з метою вторинної профрілактики здійснювали за видом АА та видом лікування (моно- чи подвійна антиагрегантна терапія тощо).

Результати й обговорення. Відомо, що інгібуючий вплив на агрегацію тромбоцитів (еритроцитів) чинять різні лз - ацетилсаліцилова кислота (АСК) (найбільш вивчена сьогодні), дипіридамол, тиклопідин та його дериват клопідогрель, блокатори рецепторів глікопротеїну IIb/IIla (ептифібатид, абсіксимаб, тирофрібан та ін.), цилостазол, тикагрелор, трифрлу-

ISSN 2312-0967. Pharmaceutical review. 2018. № 4 
зал тощо. Результати систематизації доказових даних щодо застосування різних АА при гострому II представлені в таблиці 1.
Узагальнені доказові дані стосовно ефективності та безпеки використання АТТ при гострому II наведено в таблиці 2.

Таблиця 1. Систематизація доказових даних щодо застосування різних антиагрегантів при гострому ішемічному інсульті

\begin{tabular}{|c|c|c|}
\hline Назва лЗ & $\begin{array}{c}\text { Вид доказового джерела (КО, СО чи } \\
\text { МА), автори, рік }\end{array}$ & $\begin{array}{c}\text { К-сть досліджень та учасників, } \\
\text { (n) } \\
\end{array}$ \\
\hline 1 & 2 & 3 \\
\hline $\begin{array}{l}\text { АСК, дипіридамол, клопідогрель, } \\
\text { трифрлузал, тиклопідин, цилостазол, } \\
\text { ептифрібатид }\end{array}$ & $\begin{array}{l}\text { MA, Antithrombotic } \quad \text { Trialists' } \\
\text { Collaboration, } \\
2002 \text { p. [6] }\end{array}$ & 287 РКД, $\mathrm{n}=212000$ учасників \\
\hline
\end{tabular}

Результати. Серед хворих із гострим II серйозні судинні події протягом трьох тижнів виникали на тлі ATT у 8,2 \%, а в групі контролю - у 9,1 \% пацієнтів; фратальні та нефратальні великі екстракраніальні кровотечі - у 0,97 \% і 0,57 \%, а повторні сратальні та несратальні інсульти різної етіології - у 3,49 \% та 4,03 \% пацієнтів відповідно.

\begin{tabular}{|l|l|l|}
\hline Простациклін & $\begin{array}{l}\text { КО, } \\
\text { Bath P.M.W., 2003 р. [7] }\end{array}$ & 5 К, n=191 учасник \\
\hline
\end{tabular}

Результати. Смертність протягом чотирьох тижнів у групі, яка приймала простациклін, була нижчою, ніж в групі плацебо (відношення шансів (ВШ) 0,63; 95 \% довірчий інтервал (ДІ): 0,22 - 1,85). В одному дослідженні (n=32 пацієнти) повідомлялося, що пізня смертність (від 10 до 18 місяців) в обидвох групах становила 50 \%. Висновок. Занадто мало пацієнтів вивчали в РКД, щоб зробити висновок щодо впливу лікування простацикліном на виживання людей з гострим II.

АСК, дипіридамол, клопідогрель, абсіксимаб, тирофрібан, ламіфібан, ксемілофрібан, сібафрібан, ортофрібан, ептифібатид

Результати. Лікування низькою дозою АСК (до 100 мг) та дипіридамолом пов'язані 3 найнижчим ризиком кровотечі (3,6 \% та 6,7 \% відповідно). Найвища частота ускладнень у вигляді кровотеч (44,6 \%) була пов'язана з блокаторами рецепторів глікопротеїну IIb/IIla. Вищі дози ACK ( $\geq 100$ мг) викликали відносно високу частоту геморагічних подій.

\begin{tabular}{l|l|l}
\hline Трифрлузал, АСК & $\begin{array}{l}\text { CO, Costa J., Ferro J.M., Matias-Guiu } \\
\text { J. та ін., } 2005 \text { р. [9] }\end{array}$ & 4 РКД, $\mathrm{n}=2944$ учасники \\
\hline
\end{tabular}

Результати. Не було суттєвої різниці між трифлузалом та АСК у виникненні серйозних судиннихподій (несатальний ішемічний або геморагічний інсульт) (ВШ 1,04; 95 \% ДІ 0,87 - 1,23). Разом $з$ тим виявлено істотні відмінності щодо частоти крововиливів як незначних (ВШ 1,60, 95 \% ДІ: 1,31 - 1,95), так і великих (ВШ 2,34; 95 \% ДІ: 1,58 - 3,46). Трифлузал асоціювався з меншим ризиком геморагічних ускладнень.

\begin{tabular}{l|l|l} 
ACK & KO, Sandercock P.A.G., Counsell & 8 КД, n = 41483 учасники \\
& C., Tseng M.C., Cecconi E., 2014 p. &
\end{tabular}

Результати. Виявлено значне зниження смертності або залежності в кінці спостереження у пацієнтів, які приймали АСК (ВШ 0,95; 95 \% ДІ: 0,91 - 0,99). АТТ пов'язана з невеликим, але достовірним збільшенням симптомних внутрішньочерепних крововиливів (ВЧК).

Висновок. Пероральна ААТ АСК у дозі 160 - 300 мг на добу, розпочата протягом 48 годин після появи II, зменшує ризик раннього повторного II без серйозного ризику ранніх геморагічних ускладнень та покращує віддалені результати.

\begin{tabular}{l|l|l}
\hline Абсіксимаб & КО, Ciccone A., Abraha I., Santilli I., & 2 КД, n = 474 учасники \\
& 2007 р. [11]
\end{tabular}

Результати. Лікування абсіксимабом пов'язане з незначним зниженням сумарно смертності та функціональної залежності (ВШ 0,79; 95 \% ДІ: 0,54 - 1,17). Проте воно призводило до значного збільшення симптомних ВЧК (ВШ 4,13; 95 \% ДІ: 0,86 - 19,67). Висновок. На момент дослідження не вистачало доказів РКД щодо ефективності або безпеки терапії блокаторами рецепторів глікопротеїну IIb/IIIa при гострому II.

\begin{tabular}{|c|c|}
\hline $\mathrm{ACK}$ & 365 учасників \\
\hline
\end{tabular}

$$
\text { ін., } 2014 \text { р.[12] }
$$

Результати. Лікування будь-яким із блокаторів рецепторів глікопротеїну Ilb/IIla істотно не зменшувало смертність або залежність (ВШ 0,97; 95 \% ДІ: 0,77 - 1,22 для порівняння між абсіксимабом і плацебо; ВШ 1,00; 95 \% ДІ: 0,52 1,92 для порівняння між тирофрібаном та АСК). Абсіксимаб асоціювався із значним збільшенням симптомних ВЧК (ВШ 4,6; 95 \% ДІ: 2,01-10,54), а тирофрібан - ні (ВШ 0,32; 95 \% ДІ: 0,03 - 3,19).

\begin{tabular}{l|l|r} 
Цилостазол, АCK & $\begin{array}{l}\text { MA, Tan L., Margaret B., Zhang J.H. та } \\
\text { iн., } 2015 \text { р. [13] }\end{array}$ & 9 КД, n=6328 учасників
\end{tabular}

ISSN 2312-0967. Фармацевтичний часопис. 2018. № 4 
Продовження табл. 1

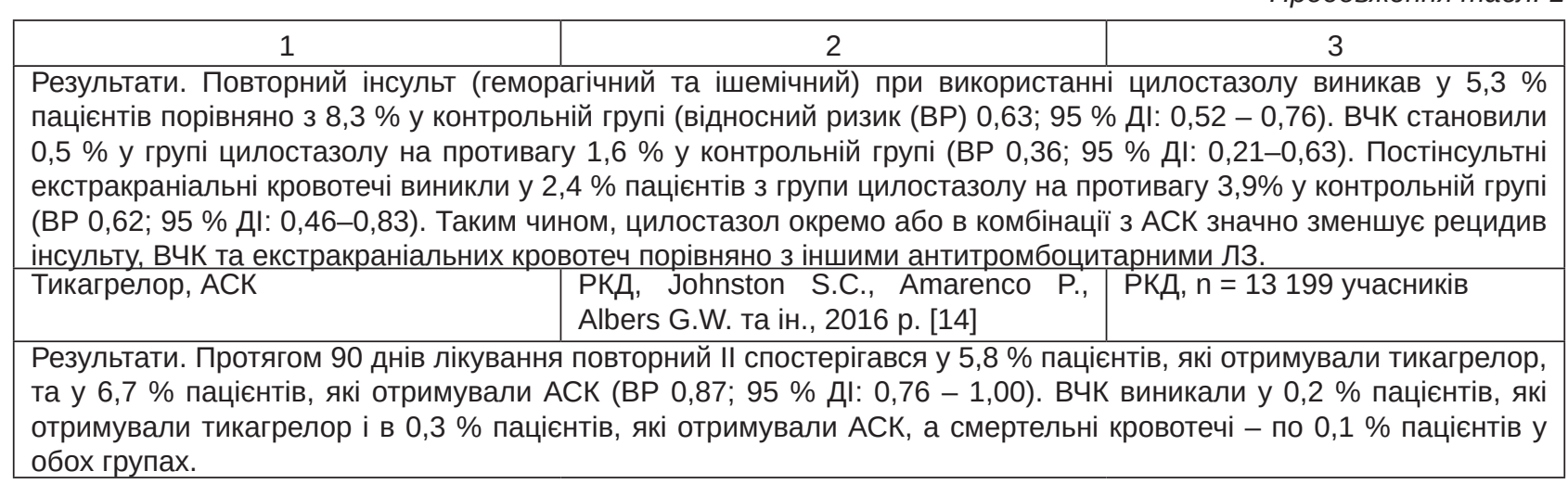

Таблиця 2. Ефрективність та безпечність антитромботичної терапії при гострому ішемічному інсульті

\begin{tabular}{|c|c|}
\hline Ефективність АТТ & Безпечність АТТ \\
\hline $\begin{array}{l}\text { АТТ знижує комбінований результат серйозних } \\
\text { судинних подій приблизно на } 1 / 4 \text {, нефратального } \\
\text { інфраркту міокарда на третину, нефратального інсульту } \\
\text { на одну чверть і судинну смертність на одну шосту [6] }\end{array}$ & $\begin{array}{l}\text { ATТ пов'язана із ризиком виникнення ускладнень } \\
\text { у вигляді кровотеч. Найвища частота ускладнень } \\
\text { у вигляді кровотеч пов'язується } 3 \text { блокаторами } \\
\text { рецепторів глікопротеїну IIb/IIla }[8,11,12] \text {, невисокий } \\
\text { ризик кровотеч - лікування дипіридамолом [8] }\end{array}$ \\
\hline $\begin{array}{l}\text { АСК. Значне зниження смертності або залежності в } \\
\text { кінці спостереження [10] }\end{array}$ & $\begin{array}{l}\text { Вищі дози АСК ( } \geq 100 \text { мг) спричиняють високу частоту } \\
\text { ускладнень у вигляді кровотеч [8], лікування АСК в } \\
\text { низькій дозі (до } 100 \text { мг) має невисокий ризик кровотеч } \\
{[8,10]}\end{array}$ \\
\hline $\begin{array}{l}\text { Цилостазол окремо або в комбінації } 3 \text { АСК значно } \\
\text { зменшує рецидив інсульту порівняно } 3 \text { іншими } \\
\text { антитромбоцитарними лЗ [13] }\end{array}$ & $\begin{array}{l}\text { Цилостазол окремо або в комбінації } 3 \text { АСК значно } \\
\text { зменшує частоту ВЧК та екстракраніальних кровотеч } \\
\text { порівняно з іншими антитромбоцитарними ЛЗ [13] }\end{array}$ \\
\hline $\begin{array}{l}\text { Абсіксимаб. Незначне зниження сумарно смертності та } \\
\text { функціональної залежності [11]. Подальші дослідження } \\
\text { засвідчили, що лікування абсіксимабом не показало } \\
\text { ознак зменшення смертності або інвалідності у тих, } \\
\text { хто вижив після ІІ. Ці дані не підтримують звичайного } \\
\text { використання блокаторів рецепторів глікопротеїну ІІb- } \\
\text { IIIа в клінічній практиці [12] }\end{array}$ & Висока частота ускладнень у вигляді кровотеч $[11,12]$ \\
\hline $\begin{array}{l}\text { Тикагрелор. Не перевершує АСК у зниженні частоти } \\
\text { повторних інсультів [14] }\end{array}$ & $\begin{array}{l}\text { Безпечність тикагрелору майже на такому ж рівні, як і } \\
\text { АСК [14] }\end{array}$ \\
\hline $\begin{array}{l}\text { Трифлузал. Не було суттєвої різниці між трифрлузалом } \\
\text { та АСК у виникненні серйозних судинних подій [9] }\end{array}$ & $\begin{array}{l}\text { Трифрлузал } \quad \text { асоціювався } \\
\text { геморагічних ускладнень [9] }\end{array}$ \\
\hline Простациклін. Занадто мало пацієнтів вивчались & бити висновок щодо ВІ \\
\hline
\end{tabular}

Таким чином, препаратом вибору для АТТ в гострому періоді II залишається АСК. Сьогодні існують обмежені дані щодо використання альтернативних антитромбоцитарних агентів при лікуванні гострого II. Однак у хворих, які мають протипоказання до використання АСК, призначення альтернативних антиагрегантів може бути доцільним [15].

Ефективність тирофрібану та ептифібатиду не є достатньо достовірною, що потребує подальших клінічних випробувань. Введення інших блокаторів рецепторів глікопротеїну IIb/IIIa, включно абсіксимаб, при лікуванні гострого II € потенційно шкідливим і не повинно виконуватись. Тому потрібні подальші дослідження тестування безпеки та ефективності цих пре- паратів. Для лікування гострого II не рекомендується також тикагрелор. Хоча він може бути розумною альтернативою для пацієнтів, які мають протипоказання до АСК $[14,15]$.

У таблиці 3 представлено систематизовані доказові дані щодо застосування АА у вигляді різних видів терапії (моно-, подвійної, претерапії перед тромболізисом) при гострому II.

Подвійна АТТ порівняно з монотерапією є безпечною та ефективною щодо зниження рецидиву II у пацієнтів з гострим II або TIA [16, 17]. Комбінована терапія низькою дозою tPA і блокаторами рецепторів глікопротеїну IIb/IIIa (абсіксимаб, ептифрібатид) порівняно із стандартною дозою tРА пов'язана зі зниженням частоти виникнення симптомних ВЧК [18].

ISSN 2312-0967. Pharmaceutical review. 2018. № 4 
Таблиця 3. Систематизація доказових даних щодо застосування антиагрегантів у вигляді різних видів терапії (моно-, подвійної, претерапії перед тромболізисом) при гострому ішемічному інсуліні

\begin{tabular}{|c|c|c|}
\hline Назва Л3 та вид терапії & $\begin{array}{c}\text { Вид доказового джерела } \\
\text { (КО, СО чи МА), автори, рік }\end{array}$ & $\begin{array}{c}\text { К-сть досліджень та учасників, } \\
\text { (n) }\end{array}$ \\
\hline $\begin{array}{l}\text { Моноантиагрегантна (АСК) / } \\
\text { подвійна (АСК + дипіридамол; АСК } \\
\text { + клопідогрель) }\end{array}$ & $\begin{array}{l}\text { CO та MA, Geeganage C.M., Diener } \\
\text { H.C., Algra A., } \\
2012 \text { p. [16] }\end{array}$ & 12 РКД; n = 3766 учасників \\
\hline
\end{tabular}

Результати. Подвійна терапія значно знижувала рецидив II (3,3\% випадків при подвійній на противагу 5,0 \% випадків при моноагрегантній терапії; відносний ризик (ВР) 0,67; 95 \% ДІ: 0,49-0,93). Збільшення кровотеч було незначним (0,9 \% при подвійній та 0,4% при монотерапії; ВР 2,09; 95 \% ДІ: 0,86-5,06).

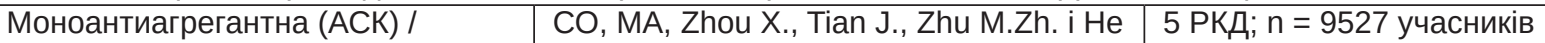

подвійна (АСК + клопідогрель) при

TIA або малому II 2017 р. [17]

Результати. При TIA або малому II комбінована порівняно з монотерапією суттєво знижувала частоту рецидивів II (ВШ 0,76; 95 \% ДІ: 0,67-0,87, p <0,0001). Крім того, не спостерігалось значного збільшення частоти судинної смертності та інсраркту міокарда (IM) (BP = 1,08, 95 \% ДІ: 0,83-1,41, p = 0,56) та суттєвої зміни основних геморагічних подій (ВР = 1,55, 95 \% ДІ: 0,72-3,36, p=0,26).

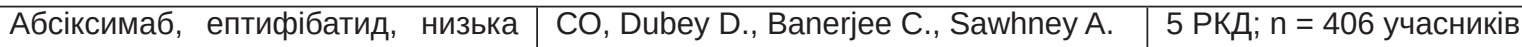
доза активатора плазміногену (tPA) та ін. , 2014 р. [18]

Результати. Комбінована терапія пов'язана із суттєвим зниженням частоти симптомних ВЧК (ВШ 0,26; 95 \% ДІ: 0,07-0,83, p=0,01) порівняно із стандартною дозою tPA. Не відрізнялися значно у двох групах фрункціональні результати (ВШ 0,87; 95 \% ДІ: 0,59-1,30, p=0,54) та смертність через 90 днів (ВШ 1,16; 95 \% ДІ: 0,69-1,93, p=0,60).

\begin{tabular}{l|l} 
АСК, клопідогрель перед & CO та MA G. Tsivgoulis, A.H. Katsanos,
\end{tabular} тромболізисом альтеплазою
7 РКД; $n=4376$ учасників (з них 33,7 \% попередньо приймали AA)

Результати. Після пристосування до віку та тяжкості інсульту претерапія АА не асоціювалася 3 більш високим ризиком ВЧК (ВШ 1,67; 95 \% ДІ: 0,75-3,72), з 3-місячною функціональною незалежністю (ВШ 0,88; 95 \% ДІ: 0,54-1,42) або смертністю (ВШ 1,01; 95 \% ДІ: 0,55-1,86).

Претерапія АА не пов'язана з більш високим ризиком виникнення симптомних ВЧК та гіршим 3-місячним фрункціональним результатом у пацієнтів, яким було проведено тромболізис. Тому попереднє використання антитромбоцитарних ЛЗ не слід сприймати як пересторогу для проведення тромболізису чи зниження дози ТPA [19].

Результати досліджень подвійної АТТ лягли в основу нових рекомендацій американських асоціацій серця та інсульту (American Heart Association/
American Stroke Association, AHA/ASA (2018). У них йдеться про те, що у хворих, які мали малий II, лікування протягом 21 дня подвійною АТТ (АСК + клопідогрель), яка почалася протягом 24 годин, може бути корисним для ранньої вторинної профрілактики інсульту для періоду до 90 днів від появи симптомів [15].

Далі ми проаналізували та систематизували доказові дані щодо використання АА у вторинній профрілактиці II (табл. 4).

Таблиця 4. Систематизація доказових даних щодо застосування антиагрегантів з метою вторинної профрілактики ішемічного інсульту

\begin{tabular}{|c|c|c|}
\hline Назва ЛЗ & $\begin{array}{c}\text { Вид доказового джерела } \\
(\text { КО, СО чи МА), автори, рік }\end{array}$ & $\begin{array}{c}\text { К-сть досліджень та учасників, } \\
\text { (n) }\end{array}$ \\
\hline 1 & 2 & 3 \\
\hline $\begin{array}{l}\text { АСК, дипіридамол, клопідогрель, } \\
\text { трифрлузал, тиклопідин, } \\
\text { цилостазол, ептисрібатид }\end{array}$ & $\begin{array}{l}\text { MA, Antithrombotic Trialists' Collaboration, } \\
2002 \text { p. [6] }\end{array}$ & 287 РКД, $\mathrm{n}=212000$ \\
\hline \multicolumn{3}{|c|}{$\begin{array}{l}\text { Результати. Серед хворих, які попередньо мали інсульт або ТІА, серйозні судинні події протягом двох років } \\
\text { виникали на тлі лікування АА у 17,8 \%, а в групі контролю - у 21,4 \% пацієнтів; фратальні та несратальні великі } \\
\text { екстракраніальні кровотечі - у групі АТТ в 0,97 \%, а в групі контролю - в 0,47 \% хворих; повторні фратальні та } \\
\text { нератальні інсульти різної етіології виникали у 10,83 \%, а в групі контролю - в 13,55 \% пацієнтів. Клопідогрель } \\
\text { зменшував кількість серйозних судинних подій на 10\% порівняно з АСК (4 \%), тиклопідин - на } 12 \% \text { (АСК на } \\
7 \text { \%). }\end{array}$} \\
\hline АСК + клопідогрель & $\begin{array}{l}\text { CO, Palacio S., Hart R. G., Pearce L. A. } \\
\text { та Benavente O. R., } 2012 \text { р. [20] }\end{array}$ & 12 РКД; n = 90934 учасників \\
\hline
\end{tabular}

ISSN 2312-0967. Фармацевтичний часопис. 2018. № 4 
Продовження табл. 4

\begin{tabular}{|c|c|c|}
\hline 1 & 2 & 3 \\
\hline \multicolumn{3}{|c|}{$\begin{array}{l}\text { Результати. Не спостерігалось значного збільшення смертності при комбінованій терапії в } 4 \text { короткочасних } \\
\text { (14 днів - } 3 \text { місяці, ВШ 0,93; } 95 \text { \% ДІ; 0,87-0,99) та у } 7 \text { довготермінових (> } 3 \text { місяців, ВР 0,97; } 95 \text { \% ДІ; 0,91- } \\
\text { 1,04) РКД. Додавання клопідогрелю до АСК було пов'язане із збільшенням кількості смертельних крововиливів } \\
\text { (ВШ 1,35; } 95 \text { \% ДІ: 0,97-1,90) та зменшенням кількості інорарктів міокарда (ВШ 0,82; } 95 \text { \% ДІ: 0,74-0,91). }\end{array}$} \\
\hline & & \\
\hline \multicolumn{3}{|l|}{$\begin{array}{l}\text { Результати. Цилостазол у профріл } \\
0,77 ; 95 \text { \% ДІ: 0,60-0,98) та низька } \\
\text { в поєднанні } 3 \text { дипіридамолом (40 } \\
\text { подій краще, ніж низькі дози АСК } \\
\text { різниця статистично не значуща. } \\
95 \text { \% ДІ: 0,79-1,16). Лікування ц } \\
\text { більшість інших схем (зокрема, АС } \\
\text { дипіридамол } 400 \text { мг (ВШ 0,62; } 95\end{array}$} \\
\hline & & \\
\hline \multicolumn{3}{|c|}{$\begin{array}{l}\text { иці інсультів загалом та геморагічних інсультів ефективніший, ніж АСК (ВШ } \\
\text {; } 95 \text { \% ДІ: 0,08-0,58 відповідно). Комбінована терапія цилостазол + АСК у } \\
\text { 'ла есрективнішою, ніж монотерапія цилостазолом. }\end{array}$} \\
\hline & & 8969 y \\
\hline \multicolumn{3}{|l|}{$\begin{array}{l}\text { Результати. Подвійна АТТ ( } \leq 1 \text { рок } \\
0,76, \text { p <0,00001) у пацієнтів } 3 \text { II а } \\
\text { та ВЧК (ВР 1,29; } 95 \% \text { ДІ: 0,56-2 } \\
\text { профріль безпеки. }\end{array}$} \\
\hline ( & & 11 \\
\hline \multicolumn{3}{|c|}{ Оиวик сопйорн } \\
\hline
\end{tabular}

Дані таблиці 4 підтверджують певну еволюцію поглядів на подвійну АТТ у вторинній профрілактиці II. Зокрема, у 2012 р. в CO Palacio S. та ін. зробили висновок, що подвійна АТТ (> 3 місяців) не впливає на загальну смертність, проте збільшує кількість смертельних крововиливів [20]. У 2016 р. в MA Liu Y. та ін. дійшли висновку, що подвійна АТT ( $\leq 1$ року) має більшу ефективність та еквівалентну безпеку порівняно 3 моноантиагрегантною терапією [23]. При тривалій профрілактиці серйозних судинних подій у пацієнтів 3 попереднім II або ТІА цилостазол був значно ефективнішим за АСК та клопідогрель [21,22]. У пацієнтів із некардіоемболічним інсультом АТТ збільшує ризик великих кровотеч із зростанням віку пацієнтів та збільшенням кількості фракторів ризику [24].

В оновлених рекомендаціях AHA/ASA (2018) вказується, що для ранньої вторинної профрілак- тики у пацієнтів з некардіоемболічним II підбір антиагрегантного Л3 слід індивідуалізувати з урахуванням фракторів ризику пацієнта, вартості, толерантності, відносної відомої ефективності Лз та інших клінічних характеристик. Препаратом вибору залишається АСК (низькі дози). Перевага від збільшення дози АСК або переходу на альтернативний антиагрегантний лз 3 метою отримання додаткової користі не є належним чином встановлена [15].

Висновок. За результатами розширеного пошуку публікацій щодо АТТ при II в різних базах даних ДМ за липень 2018 р. встановлено, що питання ефективності, безпеки лікування різними антитромбоцитарними Л3 та їх комбінаціями й надалі залишається актуальним напрямом досліджень сучасної інсультології. 
Фармакоекономіка

Pharmacoeconomics

\title{
АНТИТРОМБОЦИТАРНАЯ ТЕРАПИЯ ИШЕМИЧЕСКОГО ИНСУЛЬТА С ПОЗИЦИЙ ДОКАЗАТЕЛЬНОЙ МЕДИЦИНЫ
}

\section{О. Р. Левицкая}

\author{
Львовский национальный медицинский университет имени Данила Галицкого \\ levytska.oksana@gmail.com
}

\begin{abstract}
Цель работы. Анализ и систематизация данных кокрановских (КО), систематических обзоров (СО) и метаанализов (MA) относительно антитромбоцитарной терапии (АТТ) при ишемическом инсульте (ИИ) с учетом современных данных доказательной медицины (ДМ).

Материалы и методы. Методы: информационного поиска, анализа и синтеза. Проведен расширенный поиск КО, CO и MA по ATТ при ИИ в базах ДM DORIS и Medline (PubMed). Период исследования - июль 2018 г. В исследование включено 4 КО и 14 СО и МА (полнотекстовые обзоры или абстракты). Систематизация данных осуществлялась за видом антиагреганта и видом лечения (моно- или двойная антиагрегантная терапия и т. д.).

Результаты и обсуждение. Проанализированы и систематизированы данные по эфффективности и безопасности использования ацетилсалициловой кислоты (АСК), дипиридамола, тиклопидина, клопидогреля, блокаторов рецепторов гликопротеина Ilb / IIla (эптифрибатида, абсиксимаба, тирофибана и др.), цилостазола, тикагрелора, трифрлузала в остром периоде ИИ и при его вторичной профилактике. Препаратом выбора для АТТ как в остром периоде, так и с целью вторичной просрилактики ИИ остается АСК. У больных, имеющих противопоказания к назначению АСК, возможно использование альтернативных антиагрегантов (в частности, клопидогреля). Эффрективность и безопасность одних блокаторов рецепторов гликопротеина IIb/ IIIa (тирофибан и эптифибатид) не является достаточно достоверной, а использование других (абсиксимаб и др.) при лечении острого ИИ имеет потенциальный вред и не должно выполняться. Вопрос эсроективности и безопасности этих лекарственных средств (ЛС) при ИИ должен исследоваться в дальнейших испытаниях. Кратковременная двойная АТТ (АСК + клопидогрел) является полезной для ранней профилактики у больных с малым инсультом.

Выводы. По результатам расширенного поиска публикаций по АТТ при ИИ в различных базах данных ДМ за июль 2018 г. установлено, что вопросы эфффективности, безопасности лечения различными антитромбоцитарными лС и их комбинациями по прежнему остаются актуальным направлением исследований современной инсультологии.
\end{abstract}

Ключевые слова: ишемический инсульт; антиагреганты; доказательная медицина.

\section{ANTIPLATELET THERAPY OF ISCHEMIC STROKE FROM THE POSITIONS OF EVIDENCE-BASED MEDICINE}

\section{O. R. Levytska}

Danylo Halytsky Lviv National Medical University

levytska.oksana@gmail.com

The aim of the work. Analysis and systematization of data from Cochrane reviews (CR), Systematic reviews (SR) as well as meta-analysis (MA) regarding antiplatelet therapy (APT) in ischemic stroke (IS) including modern data of evidencebased medicine (EBM).

Materials and Methods. Methods: information search, analysis and synthesis. We conducted an extended search of CR, SR and MA on APT in IS in DORIS and Medline (PubMed) databases. Period: July 2018. The research includes 4 CR and 14 SR and MA (full-text and abstract reviews). Systematization of data was conducted by the type of antiplatelet drugs and by the type of treatment (mono or dual APT, etc).

Results and Discussion. We analyzed and systematized data on the effectiveness and safety of use of acetylsalicylic acid (ASA), dipyridamole, ticlopidine, clopidogrel, glycoprotein Ilb/llla receptor blockers (eptifibatide, abciximab, tirofiban, etc.), cilostazol, ticagrelor, triflusal in acute phase of IS and its secondary prevention. The drug of choice for both acute phase and secondary prevention of IS remains ASA. For patients with contraindications to ASA prescription alternative antiplatelet drugs (for instance, clopidogrel) can be utilized. Effectiveness and safety of some glycoprotein IIb/Illa receptor blockers (tirofiban and eptifibatide) has proved to be not sufficiently reliable and the use of others (abciximab, etc.) for acute IS is potentially harmful and should be avoided. Issue of effectiveness and safety of these medications for IS treatment should be researched in any further trials. Short-term dual APT (ASA+ clopidogrel) is useful for early prevention in patients with minor stroke.

Conclusions. Based on the results of the extended search of publications regarding APT in IS on various databases in July 2018, it was established that the issue of effectiveness and safety of treatment with variety of antiplatelet drugs and their combinations remains an important research direction in stroke studies.

Key words: ischemic stroke; antiplatelet drugs; evidence-based medicine.

ISSN 2312-0967. Фармацевтичний часопис. 2018. № 4 


\section{Список літератури}

1. Сучасні принципи діагностики та лікування хворих із гострим ішемічним інсультом та TIA. Адаптована клінічна настанова, заснована на доказах : наказ МО3 України № 602 від 03.08.2012 р. «Про затвердження та впровадження медико-технологічних документів, розроблених на засадах доказової медицини» (інсульт) [Електронний ресурс]. 2012. - Режим доступу : http://www.moz.gov.ua/ua/portal/ dn_20120127_p.html.

2. Рекомендації щодо ведення хворих 3 ішемічним інсультом та транзиторною ішемічною атакою. Адаптована клінічна настанова, заснована на доказах : наказ МО3 України № 602 від 03.08.2012р. «Про затвердження та впровадження медико-технологічних документів зі стандартизації медичної допомоги при ішемічному інсульті» [Електронний ресурс]. - 2012. - Режим доступу: http://www.moz.gov.ua/ua/portal/dn_20120803_602.html

3. Левицька О. Р. Ішемічний інсульт: клініко-фрармацевтичні аспекти : монографрія / О. Р. Левицька, Б. П. Громовик, А. Б. Зіменковський. - Львів : ТзоВ «Ліга-Прес», 2014. - 223 с.

4. DORIS. Database of Research in Stroke [Electronic resources]. - Access mode: http://www.askdoris.org/

5. PubMed: [сайт]. - Електронний ресурс. - Режим доступу: https://wuw.ncbi.nlm.nih.gov/pubmed/

6. Collaborative meta-analysis of randomised trials of antiplatelet therapy for prevention of death, myocardial infarction, and stroke in high risk patients [Electronic resources] // BMJ. 2002. - Vol. 324. - P.71. - Available from: http://www.bmj.com/ content/324/7329/71.full

7. Bath P. M.W. Prostacyclin and analogues for acute ischaemic stroke [Electronic resources] / P. M. W. Bath // Cochrane Database of Systematic Reviews. - 2004. - Issue 3. Art. No. CD000177. DOI: 10.1002/14651858.CD000177.pub2. - Available from: http://onlinelibrary.wiley.com/doi/10.1002/14651858. CD000177.pub2/abstract

8. Risk of bleeding complications with antiplatelet agents: meta-analysis of 338,191 patients enrolled in 50 randomized controlled trials [Electronic resources] / V. L. Serebruany, A. I. Malinin, R. M. Eisert, D. C. Sane // Am. J. Hematol. - 2004. - Vol.75 (1). - P. 40-47. - Available from: https://www.ncbi.nlm. nih.gov/pubmed/14695631

9. Triflusal for preventing serious vascular events in people at high risk [Electronic resources] / J. Costa, J. M. Ferro, J. Matias-Guiu [et al.] // Cochrane Database Syst. Rev. - 2005. Vol. 20;(3):CD004296. - Available from: https://www.ncbi.nlm. nih.gov/pubmed/16034926

10. Oral antiplatelet therapy for acute ischaemic stroke [Electronic resources] / P. A. G. Sandercock, C. Counsell, M. C. Tseng, E. Cecconi // Cochrane Database of Systematic Reviews. - 2014. - Issue 3. Art. No.: CD000029. DOI: 10.1002/14651858.CD000029.pub3. - Available from: http:// cochranelibrary-wiley.com/doi/10.1002/14651858.CD000029. pub3/pdf

11. Ciccone A. Glycoprotein IIb-IIla inhibitors for acute ischemic stroke [Electronic resources] / A. Ciccone, I. Abraha, I. Santilli // Stroke. - 2007. - Vol. 38, Issue 3. - P.1113-4. Available from: http://stroke.ahajournals.org/content/38/3/1113 12. Glycoprotein IIb-IIla inhibitors for acute ischaemic stroke [Electronic resources] / A. Ciccone, C. Motto, I. Abraha [et al.] // Cochrane Database of Systematic Reviews. - 2014.
- Issue 3. Art. No.: CD005208. DOI: 10.1002/14651858. CD005208.pub3. - Available from: http://onlinelibrary.wiley. com/doi/10.1002/14651858.CD005208.pub3/abstract

13. Efficacy and safety of cilostazol therapy in ischemic stroke: a meta-analysis [Electronic resources] / L. Tan, B. Margaret, J. H. Zhang [et al.] // Journal of Stroke and Cerebrovascular Diseases. - 2015. - Vol. 24 (5). - P.930-938. - Available from: https://www.ncbi.nlm.nih.gov/pubmed/25804574

14. Ticagrelor versus Aspirin in acute stroke or transient ischemic attack [Electronic resources] / S. C. Johnston, P. Amarenco, G. W. Albers [et al.] // N. Engl. J. Med. -2016. - Vol. 375 (1). - P. 35-43. - Available from: https://www.ncbi.nlm.nih.gov/ pubmed/27160892

15. AHA/ASA Guideline. 2018 Guidelines for the Early Management of Patients With Acute Ischemic Stroke: A Guideline for Healthcare Professionals From the American Heart Association/American Stroke Association [Electronic resource]. - Available from: http://stroke.ahajournals.org/content/early/2018/01/23/STR.0000000000000158

16. Dual or mono antiplatelet therapy for patients with acute ischemic stroke or transient ischemic attack: Systematic review and meta-analysis of randomized controlled trials [Electronic resources] / C. M. Geeganage, H. C. Diener, A. Algra [et al.] // Stroke. - 2012. - Vol. 43. - P.1058-1066. doi: 10.1161/ STROKEAHA.111.637686. - Available from: https://www.ncbi. nlm.nih.gov/pubmed/22282894

17. A systematic review and meta-analysis of published randomized controlled trials of combination of clopidogrel and aspirin in transient ischemic attack or minor stroke [Electronic resources] / X. Zhou, J. Tian, M. Zh. Zhu, C. K. He // Exp. Ther. Med. - 2017. - Vol. 14 (1). - P. 324-332. - Available from: https://www.spandidos-publications.com/etm/14/1/324/ abstract

18. Combination therapy of intravenous glycoprotein IIb-IIla inhibitors and low dose tissue plasminogen activator for acute ischemic stroke [Electronic resources] / D. Dubey, C. Banerjee, A. Sawhney [et al.] // Stroke. - 2014. - Vol. 45, Suppl. 1 (Abst.ATMP81). - Available from: https://www.ncbi.nlm.nih. gov/pubmed/25591675

19. Antiplatelet pretreatment and outcomes in intravenous thrombolysis for stroke: a systematic review and meta-analysis [Electronic resources] / G. Tsivgoulis, A. H. Katsanos, R. Zand [et al.] // Journal of Neurology. - 2017. - Vol. 264 (6). - P.1227-1235, DOI:10.1007/s00415-017-8520-1. - Available from: https://www.ncbi.nlm.nih.gov/pubmed/28550481

20. Effect of addition of clopidogrel to aspirin on mortality: systematic review of randomized trials [Electronic resources] / S. Palacio, R. G. Hart, L. A. Pearce, O. R. Benavente // Stroke. - 2012. - Vol. 43 (8). - P. 2157-2162. doi: 10.1161/ STROKEAHA.112.656173. - Available from: https://www.ncbi. nlm.nih.gov/pubmed/22826359

21. Antiplatelet regimens in the long-term secondary prevention of transient ischaemic attack and ischaemic stroke: an updated network meta-analysis [Electronic resources] / P. P. Niu, Z. N. Guo, H. Jin [et al.] // B. M. J. Open. - 2016. - Vol. 6 (3). - Available from: http://bmjopen.bmj.com/content/6/3/e009013 22. Antiplatelet agents for the secondary prevention of ischemic stroke or transient ischemic attack: a network meta-analysis [Electronic resources] / W. Wang, L. Zhang, W. Liu [et al.]

ISSN 2312-0967. Pharmaceutical review. 2018. № 4 
// Journal of Stroke and Cerebrovascular Diseases. - 2016. Vol. 25 (5). - P. 1081-1089. - Available from: https://www.ncbi. nlm.nih.gov/pubmed/26856461

23. Efficacy and safety of short-term dual- versus monoantiplatelet therapy in patients with ischemic stroke or TIA: a meta-analysis of 10 randomized controlled trials [Electronic resources] / Y. Liu, Z. Fei, W. Wang [et al.] // Journal of Neurology. - 2016. - Vol. 263 (11). - P. 2247-2259, DOI:10.1007/ s00415-016-8260-7. - Available from: https://www.ncbi.nlm. nih.gov/pubmed/27541045

24. Predicting major bleeding in patients with noncardioembolic stroke on antiplatelets: S2TOP-BLEED [Electronic resources] / N. A. Hilkens, A. Algra, H. C. Diener [et al.] // Neurology. - 2017. - Vol. 89 (9). - P.936-943. DOI:10.1212/ WNL.0000000000004289. - Available from: https://www.ncbi. nlm.nih.gov/pubmed/28768848

\section{References}

1. Order of the Ministry of Health of Ukraine "On approval and introduction of medical-and-technological documents for standardization of care in ischemic stroke. Modern principles of diagnosis and treatment of patients with acute ischemic stroke and TIA. Adapted clinical guideline based on evidence" from August 03, 2012, No. 602. [Electronic resource]. Available from: http://www.moz.gov.ua/ua/portal/dn_20120803_602. html [Accessed July 2018]. Ukrainian.

2. Order of the Ministry of Health of Ukraine "On approval and introduction of medical-and-technological documents for standardization of care in ischemic stroke. Recommendations for the management of patients with ischemic stroke and transient ischemic attack. Adapted clinical guideline based on evidence" from August 03, 2012, No. 602]. [Electronic resource]. Available from: http://www.moz.gov.ua/ua/portal/dn_20120803_602. html [Accessed July 2018]. Ukrainian.

3. Levytska OR, Hromovyk BP, Zimenkovskyi AB. Ischemic stroke: clinical and pharmaceutical aspects: a monograph. [Ішемічний інсульт: клініко-фрармацевтичні аспекти: монограсрія] Lviv: Ltd "Liha-Press"; 2014. Ukrainian.

4. DORIS. Database of Research in Stroke [Electronic resources]. - Available from: http://www.askdoris.org/ [Accessed July 2018].

5. PubMed: [Electronic resources]. - Available from: https:// www.ncbi.nlm.nih.gov/pubmed/ [Accessed July 2018].

6. Collaborative meta-analysis of randomised trials of antiplatelet therapy for prevention of death, myocardial infarction, and stroke in high risk patients. BMJ. 2002;324: 71.

7. Bath PMW. Prostacyclin and analogues for acute ischaemic stroke. Cochrane Database of Syst Rev. 2004;3: CD000177.

8. Serebruany VL, Malinin AI, Eisert RM, Sane DC. Risk of bleeding complications with antiplatelet agents: meta-analysis of 338,191 patients enrolled in 50 randomized controlled trials. Am J Hematol. 2004;75(1): 40-7.

9. Costa J, Ferro JM, Matias-Guiu J, Alvarez-Sabin J, Torres F. Triflusal for preventing serious vascular events in people at high risk. Cochrane Database Syst Rev. 2005;(3):CD004296. 10. Sandercock PAG, Counsell C, Tseng MC, Cecconi E. Oral antiplatelet therapy for acute ischaemic stroke. Cochrane Database Syst Rev. 2014 Mar 26;(3): CD000029. doi: 10.1002/14651858.CD000029.pub3.

11. Ciccone A, Abraha I, Santilli I. Glycoprotein IIb-IIla inhibitors for acute ischemic stroke. Stroke. 2007;38(3): 1113-4.

12. Ciccone A, Motto C, Abraha I, Cozzolino F, Santilli I. Glycoprotein IIb-Illa inhibitors for acute ischaemic stroke. Cochrane Database Syst Rev. 2014;8(3): CD005208. doi:10.1002/14651858.CD005208.pub3.

13. Tan L, Margaret B, Zhang JH, Hu R, Yin $Y$, Cao L et al.

Efficacy and safety of cilostazol therapy in ischemic stroke: a meta-analysis. J Stroke Cerebrovasc Dis. 2015;24(5): 930-8. 14. Johnston SC, Amarenco P, Albers GW, Denison H, Easton JD, Evans SR et al. Ticagrelor versus Aspirin in Acute Stroke or Transient Ischemic Attack. N Engl J Med. 2016;375(1): 35-43. 15. Powers WJ, Rabinstein AA, Ackerson T, Adeoye OM, Bambakidis NC, Becker K. et al. 2018 Guidelines for the Early Management of Patients with Acute ischemic Stroke: A Guideline for Healthcare Professionals From the American Heart Association/American Stroke Association. Stroke. 2018;49 49: e46-e99.

16. Geeganage CM, Diener HC, Algra A, Chen C, Topol EJ, Dengler $\mathrm{R}$ et al. Dual or mono antiplatelet therapy for patients with acute ischemic stroke or transient ischemic attack: Systematic review and meta-analysis of randomized controlled trials. Stroke. 2012;43(4): 1058-66.

17. Zhou X, Tian J, Zhu MZh, He CK. A systematic review and meta-analysis of published randomized controlled trials of combination of clopidogrel and aspirin in transient ischemic attack or minor stroke. Exp Ther Med. 2017;14(1): 324-32.

18. Dubey D., Banerjee C., Sawhney A., Sharma A, Alberts A. Combination therapy of intravenous glycoprotein IIb-IIla inhibitors and low dose tissue plasminogen activator for acute ischemic stroke. Stroke. 2014;45(1) (Abst.ATMP81).

19. Tsivgoulis $G$, Katsanos $A H$, Zand $R$, Sharma VK, Kohrmann M, Giannopoulos S. et al. Antiplatelet pretreatment and outcomes in intravenous thrombolysis for stroke: a systematic review and meta-analysis. J Neurol. 2017;264(6): 1227-35

20. Palacio S., Hart RG, Pearce LA, Benavente OR. Effect of addition of clopidogrel to aspirin on mortality: systematic review of randomized trials. Stroke. 2012;43 (8): 2157-62.

21. Niu PP, Guo ZN, Jin H, Xing YQ, Yang Y. Antiplatelet regimens in the long-term secondary prevention of transient ischaemic attack and ischaemic stroke: an updated network metaanalysis. BMJ Open. 2016;6(3): e009013.

22. Wang W, Zhang L, Liu W, Zhu Q, Lan Q, Zhao J. Antiplatelet agents for the secondary prevention of ischemic stroke or transient ischemic attack: a network meta-analysis. J Stroke Cerebrovasc Dis. 2016;25(5): 1081-9.

23. Liu Y, Fei Z, Wang W, Fang J, Zou M, Cheng G. Efficacy and safety of short-term dual- versus mono-antiplatelet therapy in patients with ischemic stroke or TIA: a meta-analysis of 10 randomized controlled trials. J Neurol. 2016;263(11): 2247-59. 24. Hilkens NA, Algra A, Diener HC, Reitsma JB, Bath PM, Csiba L. et al. Predicting major bleeding in patients with noncardioembolic stroke on antiplatelets: S2TOP-BLEED. Neurology. 2017;89(9): 936-43.

Отримано 01.10.2018

ISSN 2312-0967. Фармацевтичний часопис. 2018. № 4 